\title{
Intercultural Communication Competence in Multinational Competitiveness: Literature Review and Synthesis
}

\author{
Ephraim Okoro, PhD \\ Howard University \\ 2400 Sixth St NW, Washington, DC 20059, USA
}

\begin{abstract}
The increasing scope of business organizations in the first decade of the twenty-first century is drawing much scholarly attention, and the trend has been described as a fact of life that defies the stretch of human imagination. The concept of global economy has expanded consumer awareness, defined new standards and rules of operations, and increased the need for national and corporate interdependence. Multinational organizations are exploring opportunities around the world, demonstrating sensitivity towards cultural differences in order to gain from the proliferation and growth of international enterprise. Recent studies indicate that while some corporations compete successfully in the global marketplace, others have failed to sustain their competitive advantage because of cultural imperialism or inadequate acculturation of their managers on international assignment. Corporate analysts argued that the key to global business success depends on effective cross-cultural etiquette and global workforce diversity management. Other significant studies emphasized that global managers should be trained in interpersonal relationship and group communication competence, and should be equipped with cross-cultural negotiation skills that can maintain global competitiveness. Increasingly, corporations recognize the value of preparing global managers, because business objectives of are not been achieved primarily because of deficiencies in cross-cultural etiquette. Against this background, this study provides a constructive evaluation and analysis of global etiquette and cross-cultural communication for managers in international assignments. The study then proposes a strategic role for organizations to achieve adequate return on investments and to succeed in international competitiveness through cultural awareness, sensitivity, and reciprocity.
\end{abstract}

Keywords: International competitiveness, Multinational management skills cultural awareness, cultural sensitivity, Intercultural communication Intercultural competence

\section{Background}

A recent survey of business and communication literature consistently demonstrates that the twenty-first business environment is increasingly multicultural and globally-interdependent. Additionally, it indicates that corporate leaders should provide opportunities for their staff in global assignments to acquire inter-cultural business etiquette in order that they will excel in their interpersonal relationship abroad. Furthermore, training in cross-cultural etiquette will enable managers for foreign assignments to cope with cultural differences. Studies (Assante \& Yin, 2007; Chaney \& Martin, 2011) explain that global orientation helps managers relate well with people from other countries and equips them to take advantage of opportunities available in today's culturally-diverse global marketplace. As Harris and Moran (2008) argued, corporate cultures of global businesses impact how managers deal with the competitive environment, especially with basic communication etiquette. In preparing managers for multinational assignments, their training should include cultural sensitivity, understanding the importance of maintaining business relationships, and impression management. They should be informed about the complexities in international culture and human resources management. Cook and Cook (2011) stress that as businesses globalize, there continues to be a compelling need for cross-cultural awareness, knowledge of business etiquette, culture-specific management styles, and intercultural exchanges, because managers will find themselves faced with multiple challenges emanating from domestic cultural issues and traditional systems. Chhokar, Brodbeck, and House (2007) highlighted the importance of global awareness and cultural assessment across developing and developed parts of the world in order to avoid failures of global managers in their assignments. It is, therefore, critically important to appreciate such things as dressing to make lasting impressions, knowing how to introduce oneself and others during business meetings and at other businessrelated occasions, and understanding basic or appropriate communication etiquette.

With the integration of world economic systems, production and consumption activities, and markets, it has become increasingly important that corporate leaderships develop a level of sensitivity necessary to communicate and negotiate cross-culturally. The critical process of making decisions, reaching mutual agreements, and building consensus has taken a new dimension because of differences in business etiquette and ethical practices. 
As Connerley and Paul (2005) noted, cross-cultural communication skills and interpersonal negotiation competence are a pre-requisite to effective management of multination workforce. Research evidence demonstrates that corporations are increasingly establishing joint ventures, building strategic alliances, and establishing direct investments around the world.

Therefore, global managers should be adequately equipped with interpersonal and nonverbal communication competence for multinational responsibilities. Recent global trends and developments highlight the need to emphasize business etiquette and cross-cultural skills as critical management imperative, because of the increasing number of organizations establishing global strategic alliances. Additionally, the global environment of business management and marketing involves effective and efficient communication among diverse stakeholders, which makes inter-cultural communication competence and skills extremely critical.

In recent years, scholarly debates, academic discussions, and professional conferences have focused on the changing attitudes and trends in business environments. Globalization of the economy, diverse workforce, and the growth of electronic communication emphasize that appropriate business behavior leads to sustainable business relationships across nations. As Cook and Cook (2001) stressed, more than ever before business etiquette now plays a critical role in the success or failure of organizations competing for global market-share. Business etiquette transcends the use of utensils at social events and introductions at special occasions. Managers in global assignments should be trained in such essential things as wearing proper attire and in how to interact with colleagues in a variety of cultural settings, because knowing the basics of etiquette is significant to the success of international managers. In addition to administrative and educational qualifications, proper manners and acceptable conduct will be highly considered in the evaluation of a manager in overseas assignments. Indeed, the inability of managers to demonstrate good or appropriate manners and personal conduct in the workplace has been cited as conditions that determine success in multinational management.

A manager's ability to demonstrate intelligence, competence, and leadership skills as well as his or her ability to engage in appropriate business etiquette is valuable in multinational business transactions. In their study of global business etiquette, Chaney and Martin (2011) and Cook and Cook (2011) place a high premium on managers' manners, public or professional behaviors, and appropriate self-comportment when conducting official duties in international business and social settings. In addition to representing the interest of their organizations, global managers' credibility and integrity is at stake at all times based on the evaluation of etiquette. For example, in global business and social environment, appropriate and respectful behavior and conduct would include sensitivity to cultural differences when making introductions, exchanging business cards, acknowledging position and status, communicating with the proper tone across cultures, dining practices and habits, tipping etiquette, giving gifts, and using clear nonverbal communications.

\section{Intercultural Communication Skills for Multinational Organizations}

Management and communication scholars have consistently argued that the success of managers on international assignments depends largely on effective cross-cultural communication. Because of its importance, a number of highgrowth organizations competing globally make a conscious effort to hire multi-lingual people from varied cultural backgrounds and nationalities. Other organizations conduct in-house language and culture classes and training sessions to all their staff to ensure that managers going on international assignments are successful. This training, among other skills, provides cultural awareness and sensitivity sessions that equip employees for mutually-beneficial relationships with colleagues from other places. There are also a few organizations that retain the services of consultants who are experts in cross-and intercultural communication, negotiations, and etiquette to ensure that their organizations have trained managers to coordinate their affairs successful in the global economy.

As Reynolds and Valentine (2011) have determined that many corporations discovered that successful and effective communication on the international level has a positive correlation with communication on the domestic level. Because of the rapidly growing value of global commerce, it has become exceedingly useful that corporations aspiring to compete overseas invest adequate resources in cross- and intercultural communication training for their competitive advantage. Essentially, organizations aspiring for prominence in the global context should understand the strategic use of downward and upward flows of communication. Downward flows distribute information from superior to subordinate levels and these flows change considerably in various countries. For example, Hodgets and Luthans (1997) explained that the downward structure of communicating in organizations is a common practice in France and in Japan. Conversely, upward flow of organizational communication stems from subordinate to superior managers, and these communication systems are prevalent in the United States and Great Britain. These types of different communication patterns are absolutely necessary for the effectiveness of managers who will be working in foreign subsidiaries of their company. 
Studies (Reynolds \& Valentine, 2011; Cook \& Cook, 2011) have stressed that in international business management arena, the level of managerial competence and operational competitiveness of firms will depend on the level of crosscultural communication with various stakeholders and the conduct of acceptable business etiquette. Furthermore, building global business relationships among corporations depends on the innate ability and interest of managers to learn about other cultures, ethics, and etiquette as well as the training needed to help managers adjust in another cultural environment. Chaney and colleague caution that when interacting with colleagues or counterparts of other cultures in a business and negotiation context, it is important to know and respect their customs to ensure that an intended meaning is conveyed in order to avoid unintentionally offending them. Additionally, other scholars (Reynolds \& Valentine, 2011; Cardon \& Scott, 2003; Brett, 2001) see global business etiquette as a natural outgrowth of business globalization, which in many significant ways complicate the way people from different backgrounds in organizational and learning contexts behave in business situations. The authors emphasized that managers on global assignments should be trained in comparative management styles, business protocol, etiquette, and ethics.

\section{Cross-Border Management and Intercultural Communication: Decorum and Etiquette}

Management and communication scholars (Chaney \& Martin 2011; Harris \& Moran, 2000) concur that in today's global business environment, more and more managers and directors should be required to understand and appreciate people who are coming from different cultures and nationalities. They added that international management skills are needed for the increasing scope of global trades and investments for the next several decades. A number of the major multinational corporations have expanded their operations throughout developed and developing nations. Some of the businesses are direct investments and others are partnership arrangements and strategic alliances with domestic operations.

Other recent studies indicate that independent entrepreneurs and small businesses have started investing and competing in multinational marketplaces. Therefore, the current global trend of business competitiveness strongly indicates a need for the development of strategic framework for managing, negotiating, and communicating across cultures in order to achieve the investment objectives of corporations. Consistent with other cultural studies, Chaney \& Martin (2011) assert that keen awareness of cultural differences is increasingly significant to the success of global competitiveness. A good understanding and appreciation of the culture in which business is conducted can make international managers both effective and productive. However, Hodgetss \& Luthans (1997) noted the concerns of some organizations when internationalization began in the 1970s that it would be exceedingly difficult to conduct business in the same fashion around the world as a result of cultural variations, differences, and conflicts. They cautioned that any attempt to manage employees the same way across cultures would present serious challenges to many global businesses.

Studies conducted over the past decade consistently stressed the need for global training based on cross-cultural negotiation, business etiquette, and intercultural effectiveness. Globalization has assumed a megatrend in the present business environment, making it extremely critical that management teams be equipped with the appropriate mindset and cross-cultural values that makes for the effective management of workforce diversity. In preparation for global assignments, Deresky (2006) described the concept of cultural convergence, the shifting of individual management styles to accommodate the approaches that are used in other management environments. This concept involves total elimination of managerial parochialism, stereotyping, and ethnocentric behavior in relating with members of staff. An analysis of the growth of multinational corporations in the wake of globalization (Chaney \& Martin, 2011; Cook \& Cook, 2011) highlighted several factors that have been instrumental to the inability of managers to succeed in international assignments. Among these factors are negative perceptions, ethnocentric predisposition, cultural imperialism, and parochialism in evaluating a multicultural workforce. These negative values have proven to be counter-productive in the leadership of international undertaking.

\section{Managerial Communication Skills for Global Competitive Advantage}

Recent developments show that many businesses are cultivating a global focus by sourcing, producing, importing, or exporting their goods and services around the globe, which makes intercultural communication and negotiation gain substantial prominence in the international business management. Further, international business etiquette (the expected rules of behavior for intercultural communication and management) has become increasingly important because of the mobility of people. Authors Bovee and Thill (2010) stressed that learning the skills of proper etiquette in preparation for international assignment is one of the critical requirements for business success in a competitive context. As the authors stated, some behavioral rules are formal and specifically articulated and others are informal and learned over time which influences thverall behavior of majority of people in a society most of the time. 
It is noted that as managers appreciate, value, and respect cultural differences, they develop a better understanding of people's behavioral patterns which gives them a much better understanding of how to properly interact while conducting business.Success in the present global economy presents complex issues for managers preparing for international assignments. The competitive nature of multinational corporations for growth, market-share, and profitmargin calls for improvements in managerial communication strategies and an understanding of issues associated with managing in global environments.

Rue and Byars (2005) noted that over the past fifty years, many businesses from all over the world have been operating globally and have assigned their managers and directors to overseas' projects. For example, Nike operated subsidiaries in Vietnam and Indonesia, The Gap establishment has branches in Canada, France, Germany, Great Britain, and Japan. Perrier and Evian successfully expanded its operations outside of France, developed global brand and consumers. Furthermore, the success in multinational expansion of Coke, General Electric, McDonalds, and Boeing in the international business environment has been attributed to the corporate vision of sophisticated cross-cultural communication, etiquette, and sensitivity training for their managers, which prepared and positioned them effectively to manage a diverse workforce. Independent of each other, research (Harper, 1997; Brett, 2001; NBEA, 2007; Channey \& Martin, 2011) conducted over time concluded that working for multinational businesses present enormous operational, interpersonal, and group relationship challenges. Consequently, they recommended that managers should take orientation courses that would prepare them to work effectively with culturally-diverse employees and stakeholders.

Similarly, O'Rourke (2010) argued that the common factors contributing to managers' failure to perform adequately in multinational business assignments and projects are the inability to understand and adapt to foreign methodologies and interpersonal ineffectiveness. As interest in global marketplace increases, corporations should ensure that their managers adapting to new and different cultures. In their studies, Bovee and Thill (2011) concurred that corporate supervisors equally face the challenge of preparing teams to deal with interpersonal conflict in decision-making as well as difficulties of peaceful negotiations with international business partners.

\section{Universal Etiquette for Intercultural Management and Communication}

Developing global management skills is as demanding as applying cross-cultural negotiation and decision-making. Managers preparing for multinational assignments should acquire the essential skills for strategic negotiations and cross-cultural exchange in order to achieve the expected objectives and to make lasting impressions. Studies show that the process of negotiation and decision-making is culture-specific and involves a great deal of sensitivity, understanding, and reciprocity. In a critical analysis of the rules of etiquette, Deresky (2006) noted that the ability to conduct cross-cultural negotiations would not be over-stated given the convergence of cultures in global marketplaces. The integration of cultures places global managers in a position to learn the complexities associated with cultural nuances and values. Additionally, Carte \& Fox (2008) highlighted the inherent difficulties in international business because of the need to understand cultural and regulatory variations. For instance, international business etiquette requires the ability to adapt to different national processes, patterns, and acculturations. It should be noted that competitive positioning and long-term effective business operations in a multinational environment involve a sound knowledge of negotiating processes and decision-making strategies of managers from different parts of the world.

Intercultural communication scholars have stressed the importance of international managers to understand the impact of culture on negotiations with global business partners. Movius, Matsuura, Yan, and Kim (2006) noted that it is a gross fallacy to make the assumption that individuals who come to negotiation meetings demonstrate "single culture" norms, since they often have extensive international experience either through work, education, or probably from a multicultural and multilingual family, and thus have some acquaintance with various cultures. To achieve a desirable result in international negotiations, Salacuse (1998) stressed that global managers should be adequately grounded in intercultural communication and compromises. They should not only understand their own objectives in negotiations, but should know the parameters in the decision-making process. They should also understand that information may be presented in different forms and be prepared to tolerate ambiguity and a reasonable level of inconsistency. As Chaney and Martin (2011) noted, in high-context cultures, such as Japan, meaning is conveyed through body language, pauses, rephrasing as much as in the words used at negotiation meetings, whereas in a high-context culture of the United States, meaning is conveyed mainly through spoken words. In cross-cultural negotiation, both verbal and nonverbal communication is critically important and may affect reactions and flow of conversations. Similarly, mixed messages create uncomfortable feelings for international managers as they may be struggling to reconcile the inconsistencies. For instance, in the United States, direct eye contact is expected and is seen as a measure of honesty, trustworthiness, and reliability. Conversely, in China and in some parts of Africa, direct eye contact is considered rude and inappropriate. Additionally, direct eye contact with a superior or senior person demonstrates disrespect and hostility in India. 
Research evidence from business management practitioners has confirmed that Cross-cultural communication skills are essentials to achieving effective and productive international negotiations. In past years, negotiations involving managers from different backgrounds have not yielded much result because of the tone of conversation, facial expressions, and other culture-specific nonverbal cues. Therefore, managers should be equipped with appropriate knowledge and competence to manage complex business situations arising from cultural differences.

\section{Intercultural Communication and Management Effectiveness}

More recent intercultural studies (Thill \& Bovee, 2011; O’Rourke, 2011) indicate a positive correlation between effective international management and cross-cultural communication. A sound intercultural communication is vital for international managers as well as for domestic managers of multicultural and multinational businesses. Miscommunication, misinterpretation, or misunderstanding is more likely to occur among managers and employees from different ethnic backgrounds and nationalities than among managers and people from homogenous backgrounds. The ability to communicate cross-culturally and interculturally is required of managers who aspire to succeed in global assignments. Therefore, managers preparing to work in a domestic business with a diverse workforce or who are preparing to work in foreign environments should be adequately flexible and trained to adjust their communication pattern to the intended audience.

The increasing emphasis on workforce diversity in recent years makes it extremely important that domestic and global managers should devote more time to learning appropriate communication strategies, especially for effective management of a diverse organization. Communication is an essential part of a manager's duty and it takes up much time either interpersonally or with a group of employees. Effective intercultural exchange significantly determines the success of international transactions, the performance and productivity of a culturally diverse workforce, and the achievement of global business mission. Undoubtedly, culture is the foundation of communication, communication conveys culture, and the ability to communicate cross-culturally is a critical skill needed for global managers. As Deresky explained, effective cross-cultural communication indicates whether or not the receiver is from a country with a monochromic or a polychromic time system, high-context or low-context environment, collective or individualistic cultural orientation.

Furthermore, managing intercultural communication effectively in organizations requires that managers develop cultural sensitivity, be careful in encoding their messages, thoughtful in decoding and analyzing content and context, selective in choosing channels for transmission of messages. The increasing mobility of workers in global markets, expansion of international joint ventures and strategic alliances, and the presence of global entrepreneurs in developing nations makes cross-cultural communication competence inevitable. As businesses strive to achieve competitive advantage both domestically and globally, equipping managers with the critical communication skills enhances performance and improves the quality of relationships. A number of studies indicate that cross-cultural communication skills or behavior can be learned to increase the effectiveness of managers with host nationals. Improved cross-cultural communication in organizations reduces the challenges in international management

\section{Expanded Literature Review: Trends and Current Issues}

Scholars across communication disciplines have emphasized the vital role of etiquette in international business management context as well as in cross-cultural communication situations, because the ability to manage a multicultural workforce requires proper conduct of oneself at all times. In today's hectic and competitive society, etiquette might be taken for granted or seen as outdated concept, but it affects perceptions and decisions people make in the global context of management. It has never been over-emphasized that the ways a manager conducts himself/herself and interacts with colleagues have a profound effect on a company's goodwill or credibility. In addition to effective cross-cultural communication and negotiation skills, knowledge of business etiquette accounts for success of domestic and global managers. Bovee \& Thill (2011) and Chaney \& Martin (2011) in a recent analysis of managerial selfconduct, grooming and appearance, and comportment agreed that business etiquette is a major criterion in evaluating performance and overall success in a global workplace. Broadly speaking, etiquette includes a variety of behaviors, habits, and specific aspects of nonverbal communication that can impact the outcome of a manager's performance.

In a comprehensive assessment of current trends in global arena, Carte \& Fox (2008) and Yu (2007) caution that the tremendous surge in multinational business ventures in the current decade, it is vital to learn more about the different cultures and human behaviors around the world in order to reduce the chances of managerial failure. To effectively engage in productive conversations and conduct business affairs of organizations, both present and future managers interested in representing their organizations should devote time to familiarize themselves with acceptable business etiquette and ethics. 
For example, the giant retailer Wal-Mart learned an important lesson the hard way when it expanded its operations into Germany. Store clerks and managers resisted Wal-Mart's culture of always smiling at customers, because a good number of customers sometimes misunderstood and misinterpreted smiling as flirting. Because of a number of other cultural missteps, unacceptable etiquette, and poor cross-cultural communication, Wal-Mart had to leave the German marketplace (Bovee \& Thill, 2011). Indeed, becoming aware and sensitive to different countries' business etiquette is the key to establishing good business relationships with individuals and businesses in many countries. To buttress the significance of business etiquette in the success of multinational business, some countries that have conducted operations in the United States over the past decades were identified for analysis.

Evaluating business etiquette in the People's Republic of China, (Earley, 1997; Martin \& Chaney, 2011) note that most people are reserved much unlike in the United States. A United States businessperson sees personal relationship as separate from business. Friendships are quickly formed and dissolved. Hence, many view the U.S. business relationship as shallow and short-lived, while business relationships in China are treated as lifetime commitments. Further, Chinese business etiquette is directly related to the Chinese sensitivity to face. Ting-Toomey \& Kurogi (1998) and Earley (1997) refer to face as an evaluation of a person's credibility, integrity, and self image. Additionally, Cardon \& Scott (2003) explained that hundreds of phrases in the Chinese language state that face demonstrate the sophistication of face and how it relates to communication behaviors, such as global business etiquette. These authors noted that Chinese businesspersons employ a number of communication strategies designed to receive face or give face to others, such as indirectness, intermediaries, praising, requests, and shaming. In order to save face, they often try indirectness by avoiding public confrontations. Using intermediaries avoids direct confrontation, especially in conflict situations, such that a contact should always be established before representatives of business are sent to China. They believe in a winwin negotiation strategy that allows both sides to be winners in order to increase the strength and scope of relationships. Researcher Cardon and his colleague emphasized that Chinese businesspersons employ praise to recognize status and position. For instance, Chinese people often times make direct request for favors because this will signal that a business relationship is firm. It is customary for Chinese businesspersons to resort to shame when individuals violate the trust of a relationship.

When conducting business in China or in the United States with a person from China, the rules of business etiquette are controlled and determined by face giving and taking. For example, when giving introductions, remember that the surname comes first and the given name last. The introduction is accompanied by a bow which is uncommon in many other cultures (Chaney \& Martin, 2011). It was noted that out of concern for their business partners; many times, a handshake is combined with a bow so that each culture shows the other proper respect. Another specific illustration of how face influences Chinese business etiquette is the importance of the business card exchange at meetings or social gatherings. Chinese business cards represent the person to whom you are being introduced; therefore, it is polite to study the card carefully and respectfully before putting it in the pocket or on the table as a sign of respect. Indeed, as a significant demonstration of respect, the Chinese read business cards carefully and make some favorable comments while accepting them. During meetings with Chinese, it is a common practice for them to place business cards of colleagues attending the meeting in front of them on the conference table in order to properly refer to names, ranks, and titles. Usually, both hands are used when presenting and receiving cards, and they position cards strategically so that they can be read or seen easily.

Business etiquette in Great Britain is based on a strong sense of identity and nationalism. The English businessperson tends to be very matter-of-fact and tends to be very deadline oriented in business negotiations (Chaney \& Martin, 2011). Traditions and customs (etiquette) are very important to the British, as they tend to be reserved and expect others to act accordingly. Unlike businesspersons from the U.S., business friendships are not necessary (Morrison et al., 1994). Carte \& Fox (2008) note that because of their individualist culture, like the Americans, they focus on the tasks set out in their job description and think it is normal for a boss to reward individual effort. The British businesspersons' reputation of reserve is well deserved, thus so manifesting itself in their strict adherence to protocol (Martin \& Chaney, 2011) and their ability to confront adversity with courage and strength of character (Harper, 1997). The author also cautions that when conducting business in England, be careful about asking too many personal questions too quickly, partly because it makes them nervous and partly because they are naturally reserved in their culture. The British business person, while having excellent manners and decorum demonstrates inappropriate people skills.

When conducting business in England, the rules of business etiquette are controlled and determined by the English businesspersons' reserved character and strong sense of identity (Harper, 1997). For example, Martin \& Chaney (2011) explain that conservative attire of excellent quality is important in England when judging dress and appearance. There, as well as, in other European countries, dress is an indication of social and business status. Therefore, it is important to dress your best by selecting clothing made of quality fabrics with fine tailoring in Great Britain. In addition, accessories should be of high quality and reflect good taste. 
English inappropriate attire includes sweat suits and tennis shoes, which are viewed as appropriate only for athletic activities. The English businesspersons' negotiation processes also reflect their cultural characteristics; they are very formal and polite and place great value on proper protocol and etiquette (Chaney \& Martin, 2011). In addition, the authors note that the English can be tough and ruthless negotiators and can sometimes appear quaint and eccentric, many times causing other cultures to underestimate their skill. Mole (1997) adds that the English businesspersons quickly lose reserve when their basic assumptions about themselves are challenged or questioned.

Troyanovich (1972) interpretation of business etiquette in Germany is based on the formal culture of Germany that defines behavioral expectations in great detail, providing its participants with the knowledge of what to do and when to do it. Similarly, Carte \& Fox (2008) noted point out that German businesspersons respect authority and hierarchical differences. They prefer a hierarchical organizational structure because it avoids uncertainty, where power is ensured within the organization. They are autocrats who prefer formal communication when conducting business. In addition, they focus on personal achievements and truth and directness are important aspects in business. Tinsley and Woloshin (1974) add that the ideal person is one who can be relied on to do what is expected and whose behavior is predicable, steady, and not much influenced by the opinions of others or by opportunity. Further, Martin and Chaney (2011) pointed out that more recent research indicates that class status in important to Germans, and even though all people have equal rights under the law, in reality inequalities exist.

The German businesspersons' strict adherence to behavioral expectations is manifested in their standards of business etiquette. For example, being on time for all business and social engagements is more important to the German culture than any of the six countries surveyed in this paper (Axtell, 1998). Being only a few minutes late for meeting can be insulting to German managers and if you are delayed, an explanatory call is expected. In addition, the German sense of punctuality in all situations has been recognized as one of the most consistent stereotypical characteristics of the culture (Tinsley \& Woloshin, 1974). The value of time for the German businessperson is not primarily monetary, however, and there has never been any strong tendency to take time from other activities to increase the amount of time devoted to business affairs. Another example of German business etiquette reflective of their strict adherence to normative behavior is their etiquette for introductions. Martin and Chaney (2011) explain that in Germany, you always use a title when addressing someone until you are told it is okay to use first names. Troyanovich (1972) notes that German businesspersons are very time-conscious and that their preoccupation with punctuality is reflected in the formalized way time is reported to the German public. In agreement, Mole (1999) explains that there is a strong sense that the relationship between the company and the employee is contractual, thus you are paid for so many hours and you work as hard as you can for that period of time.

Bovee and Thill (2010) stated that Japan's style of business etiquette, as other Asian cultures, is based on their highcontext communication. In high-context cultures, people rely less on verbal communication and more on the context of nonverbal actions and environmental setting to convey meaning because so much of the message in carried in cues and "between the lines" interpretation. These contextual differences are apparent in the way businesspersons in Japan approach situations such as decision making and negotiating. For example, negotiators working on business deals in Japan may spend more time building relationships instead of working out contractual agreements. In other words, protecting the business relationship may be as important as making the final business decision. Martin and Chaney (2011) reported that the use of high-context communication can be very confusing to the uninitiated, nonsenitive intercultural businessperson. For example, the Japanese say "yes" for no but indicate whether "yes" is yes or really no by the context. Similarly, (Carte \& Fox, 2008) notes that high context communicators tend to communicate more implicitly. When a Japanese businessperson speaks, they expect the person to interpret what they mean by their knowledge of the cultural values that lie behind the words.

When conducting business meetings in Japan, Bovee and Thill (2011) explain that the rules of etiquette are controlled and determined by their cultural context, the pattern of physical cues, environmental stimuli, and implicit understanding that convey meaning between two members of the same culture. For instance, since the Japanese do not use the word "no" and have such subtle verbal and nonverbal cues, businesspersons from other countries must ask a number of questions to be certain they understand the intent of what is being communicated (Brett, 2001). In addition, (Carte \& Fox, 2008; NBEA 2007) argue that the aim at initial business meeting is to develop a personal trust. Much of the time in these meeting is spent exchanging information about the companies in question before discussing specific business proposals. Another example of how Japan's high-context culture affects their business etiquette is their attitude towards business relationships. As Martin \& Chaney (2011) and Watson \& Chatterjee (2006) stressed, building relationships and friendships in Japan is a necessary prerequisite for doing business in their country. Signing a contract in Japan, as well as in other Asian cultures, does not signal a sale or negotiation but a continuation of a relationship with obligations and duties in the future. 
Indeed, each of these countries has a rich tradition of behaviors and customs that contribute to their standards of business behavior/etiquette and knowing what each expects can aid in improving the business relationships that exists between different cultures.

\section{Conclusion and Final Thoughts}

As business organizations embark on global competitiveness, managing cultural differences, inter-cultural communication, and cross cultural negotiation and decision-making are the most common challenge to international management.

Success or failure in managing a diverse or multicultural workforce largely depends on the ability of managers to communicate effectively with people from different backgrounds and nationalities. International business is the outgrowth of globalization which is driven primarily by economic interdependency and advances in technology, but the success in global business ventures will be affected by the inability of international managers to understand appropriate business etiquette, customs, and values needed to conduct business among nations of the world. As a number of studies strongly indicate, an understanding cultural differences as well as effective intercultural communication competence will not only assist businesses to bridge the communication gap among countries involved in international trade negotiations, but will also enable multinational and multicultural managers to succeed multinational operations, global joint ventures, and strategic alliances. Because communication is culture-bound and culture specific, it is important that countries involved in international business devote adequate time to learn, understand, and appreciate the different ethical and cultural habits and appropriate etiquette for conducting business transactions on a global scale. The acquisition of these competitive global skills and competences will enable high-growth businesses establish a lasting strategic relationships. In light of the advantages and complexities of globalization in the twenty-first century business management, cultivating cross-cultural awareness, and developing multicultural sensitivity and global mindset by managers will lead to sustainable growth in international business.

\section{References}

Assante, M. \& Yin (2007). The global intercultural communication reader. New York: Routledge.

Bovee, C. L., \& Thill, J. V. (2010). Business communication today (10th ed.). Boston: Prentice Hall.

Brett, J. E. (2001). Negotiating globally: How to negotiate deals, resolve disputes, and make decisions across cultural boundaries. San Francisco: Jossey-Bass.

Budhwar, P. (2001). Doing business in India. International business review, 43(4), 549-568.

Cardon, P. W., \& Scott, J. C. (2003). Chinese business face: Communication behaviors and teaching approaches. Business communication quarterly66(4), 9-22.http://dx.doi.org/10.1177/108056990306600402

Carte, P., \& Fox, C. (2008). Bridging the culture gap: A practical guide to international business Communication (2nd ed.). Philadelphia: Kogan Page.

Connerley, M., \& Pedersen, P. (2005). Leadership in a diverse and multicultural environment: Developing awareness, knowledge, and skills. Thousand Oaks, CA: Sage Publications.

Chaney, L. H., \& Martin, J. S. (2011). Intercultural business communication (4th ed.). Upper Saddle River, NJ: Pearson Prentice Hall.

Chaney, L., \& Martin, J. (2006). Global business etiquette: A guide to international communication and customs. Westport, CT: Greenwood Publishing.

Cook, R. A., \& Cook, G. O. (2004). Guide to business etiquette (2nd edition). Upper Saddle River, NJ: Prentice Hall publishing.

Dresky, H. (2006). International management: Managing across borders and cultures. Upper Saddle River: NJ: Pearson/Prentice-Hall Publishing.

Early, P. C. (1997). Face, harmony, and social structure: An analysis of organizational Behavior across cultures. New York: Oxford University Press.

Harris, P. R., \& Moran R. T. (2000). Managing cultural differences. Houston, TX: Gulf Publishing Company.

Hodgetts, R. M., \& Luthans, F. (2002). International management: Culture, strategy behavior with world map. New York: NY: The McGraw-Hill publishers.

Harper, T. (1997). Passport United Kingdom: Your pocket guide to British business, customs, and etiquette. Dan Rafael, California: World Trade Press.

Martin, J. S., \& Chaney, L. H. (2006). Global business etiquette: A guide to international communication and customs. Westport, Conn: Praeger Publishers.

Mole, J. (1999). Mind your manners: Managing business cultures in Europe. London: Nicholas Brealey Publishing. 
Morrison. T., Conaway, W. A., \& Borden, G. A. (1994). Kiss, bow, or shake hands. Holrook, MA: Adams Media Corporation.

Movius, H., Matsuura, M., Yan, J., \& Kim, D. Y. (2006, October). Tailoring the mutual gains Approach for negotiations with partners in Japan, China, and Korea. Negotiation Journal, 22(4), 389435.http://dx.doi.org/10.1111/j.1571-9979.2006.00111.x

National Business Education Association. (2007). National standards for business education. (3rd ed.). Reston, VA.

O'Rourke, IV, J. S. (2010). Management Communication (4th ed.). Upper Saddle, River, NJ: Pearson Prentice Hall.

Peterson, B. (2004). Cultural intelligence: A guide to working with people from other cultures. Yarmouth, ME: Intercultural Press.

Reynolds, S., \& Valentine, D. (2011). Guide to Cross-Cultural Communication (2nd edition). Upper Saddle River, NJ: Prentice Hall publishing.

Rue, L. W., \& Byars, L. L. (2005). Management: Skills and Application (11th edition). New York, NY: McGraw-Hill publishers.

Thill, J. V., \& Bovee, C. L. (2011). Excellence in Business Communication (9th edition). Upper Saddle River, NJ: Prentice Hall publishing.

Salacuse, J. (1998, July). Ten ways that culture affects negotiating style: Some survey results. Negotiation Journal, 221-240.http://dx.doi.org/10.1111/j.1571-9979.1998.tb00162.x

Ting-Toomey, S., \& Kurogi, A. (1998). Facework competence in intercultural conflict: An updated face-negotiation theory. International Journal of Intercultural Relations, 22(2), 187-225.http://dx.doi.org/10.1016/S01471767(98)00004-2

Tinsley, R. L., \& Woloshin, D. L. (1974). Approaching German culture: A tentative analysis. Teaching German, 7(1), 125-136.

Troyanovich, J. (1972). American meets German-cultural shock in the classroom. Teaching German, 5(2), 67-79.

Watson, A., \& Chatterjee, S. (2006, June). Going international: What we can learn about international strategy, market entry, an resource allocation from the game of Go. Journal of Teaching in International Business, 17(4), 526.http://dx.doi.org/10.1300/J066v17n04_02

Yu, T., \& Cannella, A. (2007, June). Rivalry between multinational enterprises: An event history approach. Academy of Management Journal, 50(3), 665-686.http://dx.doi.org/10.5465/AMJ.2007.25527425

Ephraim Okoro, MBA, $\mathrm{PhD}$, is an associate professor of strategic business communication and marketing at Howard University. His research interests probe the interface between intercultural communication and workforce diversity in the context of globalization. He teaches strategic business communication, management communication, marketing communication, and marketing strategy. Contact Dr. Ephraim Okoro at Howard University, School of Business, Department of Marketing, 2600 - Sixth Street, NW, Washington, D.C. 20059; email: eaokoro@ howard.edu. 